\title{
Records of Streblidae (Diptera: Hippoboscoidea) in a tropical dry forest fragment in Colombia
}

\author{
Registros de Streblidae (Diptera: Hippoboscoidea) en un \\ fragmento de bosque seco tropical en Colombia
}

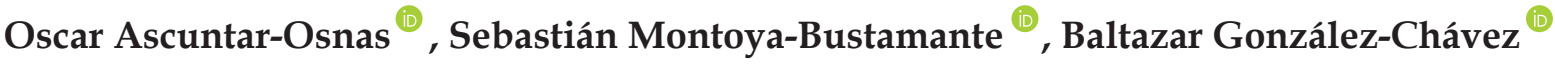

\begin{abstract}
Streblidae is a highly specialized fly family, which feeds exclusively on bats. Here we present information about the species of streblids occurring in two fragments of tropical dry forest in Cauca, Colombia. Between April and November 2012, we conducted 16 capture events of bats using mist nets, which were open from 18:00 until 06:00. Each captured bat was identified and the ectoparasites found were preserved in $90 \%$ alcohol solution. A total of 85 ectoparasites were collected and 10 species of streblids were identified in seven bat species. Our analysis showed that these parasites are locally specialized, which strongly contrasts with the high number of host species that have been reported for them. We hypothesize that this discrepancy is due to local constraints that filter the fundamental niche of these flies. This work enriches the inventories of the entomofauna in remnants of tropical dry forest, an ecosystem in a critical state of conservation.
\end{abstract}

Key words. Batflies. Bats. Fragmentation. Host.

\section{Resumen}

Streblidae es una familia de moscas altamente especializada, la cual se alimenta exclusivamente de murciélagos. Aquí se presenta información sobre las especies de Streblidae presentes en dos fragmentos de bosque seco tropical en Cauca, Colombia. Entre abril y noviembre de 2012 se realizaron 16 jornadas de captura de murciélagos, utilizando redes de niebla, las cuales estuvieron abiertas desde las 18:00 hasta las 06:00. Cada murciélago capturado se revisó y los ectoparásitos encontrados se conservaron en alcohol al 90\%. Se recolectaron 85 ectoparásitos y se identificaron 10 especies de estréblidos en siete especies de murciélagos. El análisis mostró que estos parásitos son localmente especializados, lo cual contrasta fuertemente con el alto número de especies hospederas que han sido reportadas para ellos. Se hipotetiza que esta diferencia se debe a restricciones locales que filtran el nicho fundamental de estas moscas. Este trabajo enriquece los inventarios de la entomofauna en remanentes de bosque seco tropical, un ecosistema en estado crítico de conservación.

Palabras clave. Fragmentación. Hospederos. Moscas ectoparásitas de murciélagos. Murciélagos. 


\section{Introduction}

Streblidae and Nycteribiidae are highly specialized families of dipteran, which feed exclusively on bat blood (Wenzel et al., 1966). Most species in these families are ectoparasites, except for females within the genus Ascodipteron, which live inside their host's skin (Wenzel et al., 1966; Dick \& Patterson, 2006; Dittmar et al., 2006). Several studies have found that at a given site, $71-88 \%$ of these bat flies species are host-specific (Wenzen et al., 1966; ter Hofstede et al., 2004; Dick \& Gettinger, 2005; Dick, 2007; de Vasconcelos et al., 2016; Urbieta et al., 2019). However, some species are widely distributed and have been recorded on several hosts (e.g., Paratrichobius longicrus [Urbieta et al., 2019], and some species of Trichobius and Strebla [de Vasconcelos et al., 2016]), but never outside their primary host's distribution, and commonly within closely related species or a particular clade (Dick \& Patterson, 2006). Although some authors have proposed that registered polyxenic species (i.e., parasite several hosts) may be the result of inappropriate handling (Dick, 2007), natural factors may also cause this, such as species mobility (Marshall, 1981), habitat quality (e.g., Urbieta et al., 2019), or the absence of the primary host (Dick et al., 2009).

Morphology within this group is variable: wings can be normal, reduced or absent; eyes can or cannot be present; the body is laterally or dorsally compressed; and the legs can be short and strong or long and thin (Beloto et al., 2005). These species are adenotrophic viviparous; only one larva develops inside the female and feeds on secretions from the accessory glands, which are highly specialized. Eventually, the third-instar larva is deposited as a sessile prepupa in a substrate (Overal, 1980; Fritz, 1983). The pupa forms and remains in this state for at least four weeks; then, the adult emerges and proceeds to locate its new host.

Streblidae are distributed worldwide and include 5 subfamilies, 33 genera, and at least 239 species; like its hosts, this family has pantropical distribution. While the subfamilies Ascodipterinae and Brachytarsininae are restricted to the Old World, Nycterophiliinae, Streblinae, and Trichobiinae are confined to the New World, with a higher species and host richness (Dick \& Patterson, 2006; Morse et al., 2013). Vast literature has been published on the taxonomy of this group, particularly in America (Wenzel et al., 1966; Wenzel, 1976; Guerrero, 1993; 1994a; 1994b; 1995a; 1995b; 1996; 1997; Autino et al., 1999; 2000; Graciolli \& Carvalho, 2001;
Dick \& Gettinger, 2005; Dick \& Miller, 2010). However, this group is considered paraphyletic (Dittmar et al., 2006), and few information on phylogenetic relationships exists (Dittmar et al., 2006).

In Colombia, 73 species have been recorded by Bequaert (1940), Tamsitt \& Fox (1970), Marinkelle \& Grosse (1981), Guerrero (1997), Dick et al. (2016), and in the Field Museum of Natural History database lists (http:/ / emuweb.fieldmuseum.org). However, lists of species occurring in tropical dry forest are lacking in the literature (Calonge-Camargo \& Pérez-Torres, 2018; Durán et al., 2017; Tarquino-Carbonell et al., 2015). The goal of this research was to update the information on several species of Streblidae, contributing to the biological inventory in this ecosystem, which is critically endangered in Colombia (Arango et al., 2003; Arcila et al., 2012), and providing insights on their ecology.

\section{Study Area}

This study was carried out in the vereda El Carbonero, Santander de Quilichao, in northern Cauca department, Colombia (02 $59^{\prime} 9.6^{\prime \prime} \mathrm{N}, 76^{\circ} 28^{\prime} 44.4^{\prime \prime} \mathrm{W}$ and $\left.02^{\circ} 59^{\prime} 27.6^{\prime \prime} \mathrm{N}, 76^{\circ} 28^{\prime} 30.0^{\prime \prime} \mathrm{W}\right)$. Two tropical dry forest fragments were sampled near the western slope of the Andean Central Cordillera, at 1132-1174 m a.s.l. The fragments are surrounded by bushy vegetation, and low pastures for cattle; human intervention such as deforestation, use of river water, and hunting, take place in the area.

\section{Method}

Both forest fragments were sampled during 16 visits between April and November 2012. Sampling during each event spanned 12 hours (from 18:00 to 06:00h), and consisted of 8 mist nets $12 \mathrm{~m}$ long by $3 \mathrm{~m}$ high, which were revised at one-hour intervals. Sampling effort was 1536 net-hours and $4608 \mathrm{~m}^{2}$ of total studied area, equally divided within the two fragments (768 net-hours and $2304 \mathrm{~m}^{2}$ per fragment).

Ectoparasites were visually sought (by active in-fur searching), and specimens were collected and preserved in $90 \%$ ethanol for further identification. Bats were identified following Gardner (2007) and Díaz et al . (2016) species keys. Ectoparasites were identified using 
the keys in Wenzel et al. (1966), Wenzel (1976), and Guerrero (1993, 1994a, 1994b, 1995a, 1995b, 1996). All specimens were placed in the Museo de Entomología de la Universidad del Valle (MUSENUV). Host and distribution information was compiled from Guerrero (1997), Graciolli \& Carvalho (2001), Dick et al. (2016) and the ectoparasite database of The Field Museum of Natural History.

Using field data, we constructed an interaction matrix, with bat species in rows and streblids in columns. Cells in this matrix were filled with the number of individuals collected from any given bat species, as a proxy for interaction frequency. Then we calculated the interaction exclusiveness index $\mathrm{H}^{\prime}$ 2 (Blüthgen et al., 2006). This index varies from 0.0 (generalized interactions) to 1.0 (specialized interactions), providing information on interaction specialization at community level. The significance of this index, i.e. whether the observed specialization could be explained by chance alone, was assessed by generating 1000 random matrices with the Patefield (1981) model and using as P value the proportion of these matrices with $H^{\prime} 2$ higher than the observed matrix. This analysis was performed using the bipartite (Dormann et al., 2009) package of $\mathrm{R}$ (R Core Team, 2014).

\section{Results}

We recorded ten species of streblids on seven different bat species. From these, eight streblid species are new records for Cauca department, and particularly for the highly endangered tropical dry forest. The flies Exastinion clovisi and Anastrebla modestini were recorded for the first time parasitizing the bat Anoura carishina. We found a high and significant interaction exclusiveness $\left(H^{\prime}{ }_{2}=0.97, P<0.001\right)$, indicating that streblids in our study site showed highly specialized interactions.

\section{Streblinae}

Anastrebla modestini Wenzel, 1996. Figure 1A.

Examined specimens: A female on Anoura carishina (Phyllostomidae). Accession number: MUSENUV-28179.

Distribution: From Mexico to Brazil and Bolivia.

Colombian records: Cundinamarca, Huila, and Nariño. Other hosts recorded in Colombia: Artibeus lituratus,
Enchisthenes hartii, and Sturnira erythromos (Phyllostomidae).

Other known hosts: Phyllostomidae: Anoura cultrata, A. caudifer, A. peruana, A. latidens, Carollia perspicillata, Glossophaga soricina, Lichonycteris obscura, Lionycteris spurrelli, Lonchophylla robusta.

Comments: This genus comprises five species, distributed in Central and South America. This is the most common species, and its type host is Anoura geoffroyi (Guerrero, 1997). This is the first record of Anastrebla modestini as a parasite of Anoura carishina.

\section{Metelasmus pseudopterus Coquillett, 1907. Figure 1B.}

Examined specimens: A male on Artibeus lituratus (Phyllostomidae). Accession number: MUSENUV-28184.

Distribution: From Mexico to Argentina.

Colombian records: Meta and Putumayo. No other hosts have been recorded in Colombia.

Other known hosts: Emballonuridae: Peropteryx macrotis. Phyllostomidae: Artibeus amplus, A. fimbriatus, A. fraterculus, A. jamaicensis, A. planirostris, Enchisthenes hartii, Carollia perspicillata, C. sowelli, Chiroderma villosum, Dermanura gnoma, Glossophaga soricina, Phyllostomus discolor, P. hastatus, Platyrrhinus helleri, Uroderma magnirostrum, Vampyriscus nymphaea. Vespertilionidae: Myotis nigricans.

Comments: This genus comprises two species. The cited species presents a wide geographic distribution and low specificity; however, it is not abundant. Its most common hosts are different species of Artibeus (Graciolli \& Dick, 2004; Guerrero, 1997). The type host is Artibeus lituratus (Phyllostomidae).

\section{Trichobiinae}

Aspidoptera delatorrei Wenzel, 1966. Figure 1C.

Examined specimens: A female and three males on Sturnira lilium (Phyllostomidae). Accession numbers: MUSENUV- 28180, 28181, 28182.

Distribution: From Mexico to Colombia and western Venezuela

Colombian records: Cauca, Meta, Santander, Tolima, and Valle del Cauca. Other hosts recorded in Colombia: 
Desmodus rotundus, Sturnira erythromos, and S. ludovici (Phyllostomidae).

Other known hosts: Mormoopidae: Pteronotus gymnonotus. Phyllostomidae: Carollia perspicillata, Dermanura tolteca, Glossophaga commissarisi, G. soricina, Phyllostomus hastatus.

Comments: The genus comprises three species, easily recognizable by its small size, short feet and sma11 rounded wings with well-defined veins (Autino, 2000; Guerrero, 1997). Type host: Sturnira parvidens (Phyllostomidae).

Exastinion clovisi (Pessôa \& Guimarães, 1936). Figure $1 \mathrm{D}$.

Examined specimens: Two females on Anoura carishina (Phyllostomidae). Accession number: MUSENUV 28183.

Distribution: From Mexico to Venezuela and Brazil.

Colombian records: Antioquia, Cundinamarca, and Nariño. Other hosts recorded in Colombia: Artibeus sp. and Sturnira bidens (Phyllostomidae).

Other hosts: Emballonuridae: Peropteryx macrotis. Mormoopidae: Pteronotus parnellii. Natalidae: Natalus stramineus. Phyllostomidae: Anoura cultrata, A. geoffroyi, A. peruana, A. latidens, Artibeus jamaicensis, Glossophaga soricina, Leptonycteris sp., Sturnira lilium.

Comments: This genus comprises three species, all of which parasitize bats in the genus Anoura (Dick \& Graciolli, 2013; Guerrero, 1997). Type host: Anoura caudifer (Phyllostomidae). This is the first record of Exastion clovisi as a parasite of Anoura carishina.

\section{Megistopoda aranea (Coquillet, 1899). Figure 1E.}

Examined specimens: A male on Artibeus lituratus (Phyllostomidae). Accession number: MUSENUV - 28186.

Distribution: From Mexico to Argentina.

Colombian records: Cundinamarca, Tolima, Valle del Cauca, and Vichada. Other hosts recorded in Colombia: Artibeus jamaicensis, Platyrrhinus spp., and Sturnira lilium (Phyllostomidae).

Other hosts: Noctilionidae: Noctilio leporinus. Phyllostomidae: Artibeus fimbriatus, A. fraterculus, A. hirsutus,
A. intermedius, A. lituratus, A. obscurus, A. planirostris, Brachyphylla cavernarum, Carollia castanea, C. perspicillata, Chiroderma villosum, Chrotopterus auritus, Dermanura anderseni, Dermanura cinerea, Desmodus rotundus, Diphylla ecaudata, Glossophaga longirostris, G. soricina, Lonchorhina aurita, Lophostoma silvicola, Monophyllus redmani, Phylloderma stenops, Phyllostomus discolor, P. hastatus, Platyrrhinus lineatus, P. vittatus, Sturnira ludovici, Trachops cirrhosus, Uroderma bilobatum, Vampyressa bidens, $V$. pusilla. Vespertilionidae: Myotis sp.

Comments: The genus Megistopoda includes three described species, widely distributed along the Neotropics. However, its taxonomy is hazy, due to morphological variation within populations (Dick \& Graciolli, 2013; Guerrero, 1997). M. aranea is one of the most common species in the genus. Type host: Unknown.

\section{Megistopoda proxima (Seguy, 1926). Figure 1F.}

Examined specimens: Five females and four males on Sturnira lilium (Phyllostomidae). Accession numbers: MUSENUV - 28187, 28188, 28189, 28190, 28191.

Distribution: From Mexico to Argentina; West Indies.

Colombian records: Cauca, Nariño, Putumayo, Santander, Tolima, and Valle del Cauca. Other hosts recorded in Colombia: Carollia perspicillata, Chiroderma spp., and Platyrrhinus dorsalis (Phyllostomidae).

Other hosts: Noctilionidae: Noctilio leporinus. Mormoopidae: Pteronotus parnellii. Phyllostomidae: Artibeus fimbriatus, A. hirsutus, A. jamaicensis, A. lituratus, A. obscurus, Carollia perspicillata, Chiroderma villosum, Dermanura cinerea, D. phaeotis, Desmodus rotundus, Enchisthenes hartii, Glossophaga commissarisi, G. soricina, Leptonycteris curasoae, Lonchorhina aurita, Macrotus waterhousii, Phylloderma stenops, Phyllostomus discolor, P. hastatus, Platyrrhinus helleri, P. lineatus, P. umbratus, Sturnira bidens, S. erythromos, S. parvidens, S. ludovici, S. mordax, S. oporaphilum, S. tildae, Uroderma bilobatum, U. magnirostrum.

Comments: As is common in the genus, this species presents a wide morphological variation in chaetotaxy, wings, and postgonites. They parasite mostly Sturnira spp. (Dick \& Graciolli, 2013; Guerrero, 1997). Type host: Unknown.

Paratrichobius longicrus (Miranda-Ribeiro, 1907). Figure 1G. 
Examined specimens: 21 females and 28 males in Artibeus lituratus (Phyllostomidae). Accession numbers: MUSENUV - 28185, 28192, 28193, 28194, 28195, 28196, 28197, 28198, 28199, 28200, 28201, 28202, 28203, 28204, 28205, 28206, 28207, 28208, 28209, 28210, 28211.

Distribution: From Mexico to Argentina.

Colombian records: Antioquia, Cundinamarca, Huila, Meta, Nariño, Norte de Santander, Putumayo, Santander, Tolima and Valle del Cauca. Other hosts recorded in Colombia: Artibeus jamaicensis and Phyllostomus elongatus (Phyllostomidae).

Other hosts: Molossidae: Cynomops planirostris, Molossops temminckii, Tadarida brasiliensis. Noctilionidae: Noctilio albiventris. Phyllostomidae: Artibeus concolor, A. fimbriatus, A. intermedius, A. lituratus, Dermanura azteca, D. cinerea, D. tolteca, Enchisthenes hartii, Carollia perspicillata, Desmodus rotundus, Mesophylla macconnelli, Glossophaga soricina, Phyllostomus hastatus, Platyrrhinus aurarius, P. brachycephalus, $P$. dorsalis, $P$. lineatus, $P$. umbratus, $P$. vittatus, Pygoderma bilabiatum, Sturnira lilium, S. ludovici, S. oporaphilum, Uroderma bilobatum.

Comments: The genus comprises six described species and probably more to be described. Due to its taxonomical complexity, as a result of population variation, this group requires a detailed revision. Therefore, $P$. longicrus has been suggested as a species complex (Graciolli et al., 2001; Guerrero, 1997). Type host: Artibeus jamaicensis (Phyllostomidae).

\section{Trichobius costalimai Guimarães, 1938. Figure 1H.}

Examined specimens: Three females and five males on Phyllostomus discolor (Phyllostomidae). Accession numbers: MUSENUV - 28220, 28221, 28222, 28223.

Distribution: From Guatemala to Brazil and Bolivia.

Colombian records: Chocó, Cundinamarca, Meta, and Tolima. Other hosts registered for the country: Artibeus lituratus, Carollia perspicillata (Phyllostomidae), and Molossus bondae (Molossidae).

Other hosts: Phyllostomidae: Anoura geoffroyi, Artibeus jamaicensis, Carollia perspicillata, Chrotopterus auritus, Desmodus rotundus, Phyllostomus discolor, P. hastatus, Sphaeronycteris toxophyllum, Sturnira lilium, S. Iudovici, Tonatia bidens. Vespertilionidae: Myotis nesopolus.
Comments: This is the richest genus of Streblidae; it is divided in nine groups (Dick \& Graciolli, 2013; Guerrero, 1994). Trichobius costalimai is one of the most abundant and widely distributed species; it belongs to the longipes complex, and its usual host is $P$. discolor (Guerrero, 1994). Type host: Unknown.

Trichobius joblingi Wenzel, 1966. Figure 1I.

Examined specimens: Five females and a male on Carollia castanea. Two males on Carollia perspicillata; a male on Phyllostomus discolor (Phyllostomidae). Accession numbers: MUSENUV - 28213, 28214, 28215, 28216, 28217, 28218.

Distribution: From Mexico to Brazil and Paraguay.

Colombian records: Antioquia, Bolívar, Córdoba, Cundinamarca, Huila, Meta, Nariño, Norte de Santander, Putumayo, Santander, Tolima, Valle del Cauca, and Vaupés. Other hosts recorded in Colombia: Artibeus jamaicensis, A. lituratus, Phyllostomus elongatus, $P$. dorsalis, Desmodus rotundus, Glossophaga soricina, Sturnira lilium (Phyllostomidae), Natalus tumidirostris (Natalidae), Molossus molossus (Molossidae), Myotis nigricans (Vespertilionidae) and Rhynchonycteris naso (Emballonuridae).

Other hosts: Emballonuridae: Saccopteryx bilineata. Molossidae: Molossus ater, M. molossus. Mormoopidae: Pteronotus parnellii. Natalidae: Natalus stramineus. Noctilionidae: Noctilio leporinus. Phyllostomidae: Anoura caudifer, A. geoffroyi, Artibeus fimbriatus, A. fuliginosus, A. intermedius, A. lituratus, A. obscurus, Enchisthenes hartii, Carollia brevicauda, C. sowelli, C. subrufa, Chiroderma villosum, Choeroniscus sp., Dermanura anderseni, D. phaeotis, D. watsoni, Glossophaga commissarisi, G. leachii, G. longirostris, G. soricina, Lampronycteris brachyotis, Lonchophylla robusta, Lonchorhina aurita, Lophostoma silvicola, Macrophyllum macrophyllum, Micronycteris brachyotis, M. hirsutus, M. megalotis, M. minuta, Mimon cozumelae, Phyllostomus hastatus, P. latifolius, P. dorsalis, Platyrrhinus helleri, Rhinophylla pumilio, Sturnira erythromos, S. lilium, S. parvidens, S. ludovici, S. tildae, Trachops cirrhosus, Trinycteris nicefori, Uroderma bilobatum, Vampyrodes caraccioli. Vespertilionidae: Myotis nigricans, M. ruber, Rhogeessa io.

Comments: A common and abundant species in the Neotropics. Guerrero (1995) mentions that there may be several new species within this taxon. Type host: Carollia perspicillata (Phyllostomidae). 
Trichobius longipes (Rudow, 1871). Figure 1J.

Examined specimens: A male on Phyllostomus hastatus (Phyllostomidae). Accession number: MUSENUV 28219.

Distribution: From Guatemala to Brazil and Paraguay.

Colombian records: Antioquia, Huila, Magdalena, Meta, Norte de Santander, and Valle del Cauca. Other hosts recorded in Colombia: Carollia perspicillata, Phyllostomus elongatus, Lophostoma silvicola, Vampyrum spectrum (Phyllostomidae) and Noctilio leporinus (Noctilionidae).

Other hosts: Emballonuridae: Rhynchonycteris naso. Molossidae: Molossus ater, M. rufus. Mormoopidae: Pteronotus parnellii. Phyllostomidae: Anoura geoffroyi, Artibeus jamaicensis, Choeronycteris mexicana, Desmodus rotundus, Glossophaga soricina, Phyllostomus discolor, Sturnira erythromos, S. ludovici, Uroderma bilobatum, Vampyrum spectrum.

Comments: The cited species belongs to the "longipes" complex. This species is commonly found in P. hastatus throughout its range of distribution. Type host: Phyllostomus hastatus (Phyllostomidae).

\section{Discussion}

Bat flies (Streblidae) have often been recognized as parasites with high host specificity, with each species interacting with only a few bat hosts (Dick \& Patterson, 2006). This claim is consistent with the usually highly specialized interaction reported in studies from other tropical dry forests (e.g., Zarzúa-Carbajal et al., 2016; Durán et al., 2019, de Vasconcelos et al., 2016), including this one. However, it contrasts strongly with the high number of host species reported in the literature (e.g., Dick et al., 2016) for the streblids species found at our study site. As shown above, in some cases ectoparasites species have been reported from bat species in several families.

Some authors have highlighted that accidental associations due to inappropriate handling or studies based on museum skins may yield unreliable results (ter Hofstede et al., 2004; Dick, 2007). However, even when this factor is controlled, several bat fly species may naturally parasite many hosts and this varies across study sites.
For example, in our study T. longipes was registered as host-specific, parasitizing only the bat $P$. hastatus. Yet, in other studies $T$. longipes has been recorded for several species (e.g., Dick et al., 2009; de Vasconcelos et al., 2016). It is likely that local factors determine whether bat flies in a given community are monoxenic or polyxenic. For instance, habitat disturbance (de Vasconcelos et al., 2016; Urbieta et al., 2019) could be related to the elimination of some natural barriers (Combes, 1991), favoring polyxenic ectoparasites and varying from one locality to the other. On the other hand, larger scale factors as a bigger fundamental niche of these parasites than what is usually attributed (Dick et al., 2009, but see Fritz [1983] for immunological discussion), and other factors as climate seasonality, vegetation type, bat behavior, and primary host absence (Dick et al., 2009; Pilosof et al., 2012; Zarzúa-Carbajal et al., 2016; Barbier \& Graciolli, 2016), could filter this wide range of possible interactions. Therefore, future studies that address host-specificity at a wider scale could clarify whether this phenomenon is a matter of scale.

The Colombian tropical dry forests, for example, have been intensively disturbed by humans for a long time, due to their climate and fertility of their soil. It is estimated that from its original distribution area $(80000$ $\mathrm{km}^{2}$ ), there is only about $8 \%$ left, being the Cauca river valley one of the most affected and vulnerable (García et al., 2014). In the case of dry forest from central and western Colombia (Valle del Cauca-Cauca), this deforestation has been drastic, preserving few fragments of 1 to 73 ha, surrounded by highly intervened matrices, formed by large extensions of crops and pastures (Armbrecht et al., 2001; Arcila et al., 2012), creating a panorama of uncertainty for the species that live there. Colombia has a considerable bat richness, with about 198 recorded species (Solari et al., 2013). In the Cauca department, at least 103 species occur (RamírezChaves \& Pérez, 2010). Despite this, less than 50\% of the species have been recorded as hosts of Streblidae. At least one-half of the bat flies found in this study have been recorded before in other Colombian dry forests (Tarquino et al., 2015; Durán et al., 2017; CalongeCamargo \& Pérez-Torres, 2018). However, both the most captured bat species and the most recorded bat fly differed. In our study site, the bat Artibeus lituratus and the bat-fly Paratrichobius longicrus were the most frequently recorded species interacting with each other, whereas Tarquino et al. (2015) and Calonge-Camargo \& Pérez-Torres (2018), recorded Carollia perspicillata and Trichobius joblingi as the most frequently recorded bat and bat-fly species, respectively. Considering that the 


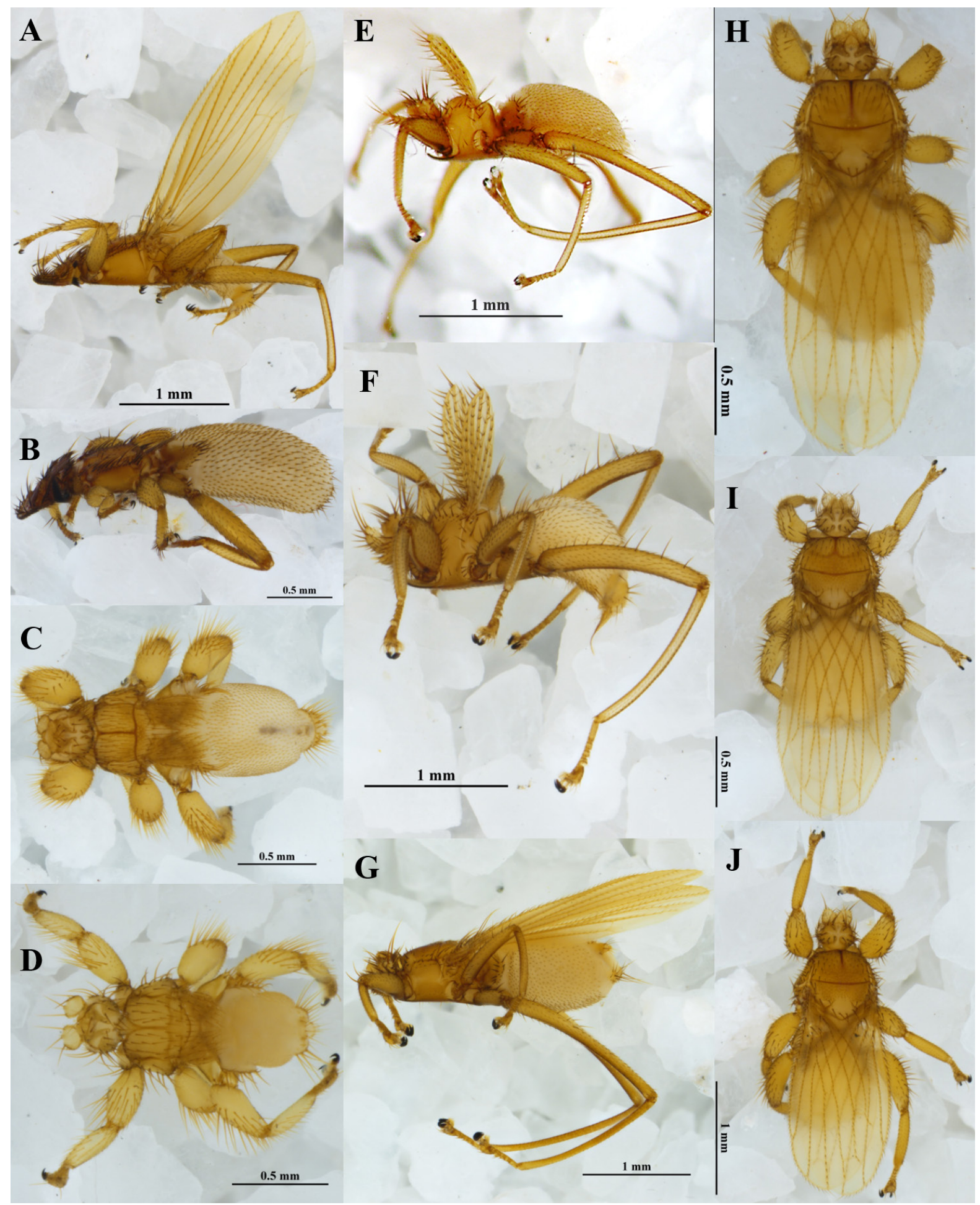

Figure 1. Species of Streblidae occurring in dry forest in vereda El Carbonero (Santander de Quilichao, Cauca, Colombia). Streblinae: A, Anastrebla modestini; B, Metelasmus pseudopterus. Trichobiinae: C, Aspidoptera delatorrei; D, Exastinion clovisi; E, Megistopoda aranea; F, Megistopoda proxima; G, Paratrichobius longicrus; H, Trichobius costalimai; I, Trichobius joblingi; J, Trichobius longipes. 
richness of bat flies is closely related to the richness of their hosts (Barbier \& Bernard, 2017) it can also be expected that the abundance of parasites is also promoted by their host abundance.

Our study area like many other dry forest relicts in the Cauca River basin retains as considerable species richness, despite its size (Arcila et al., 2012; MontoyaBustamante et al., 2016). In this locality, 18 species of bats have been recorded (Montoya-Bustamante et al., 2013) in which 10 species of streblids were found. On the other hand, we also observed that locally, the realized niche of these parasites is highly specialized, which does not mean that their fundamental niche also is. For this reason, larger scale studies and further sampling of bat ectoparasites are necessary, in order to better understand the ecology and diversity of streblids in Colombia. This will help to establish the relationships between different biomes and their fauna.

\section{Acknowledgements}

The authors sincerely thank Ana María Soria, Laura Obando, Daniela Arenas-Viveros, Mario F. GarcésRestrepo, Sasha Velazco, and Natalya Zapata-Mesa for their support during fieldwork. Also, to Dr. Ricardo Guerrero for his help in confirming the doubtful genus Trichobius. To Grupo de Investigación en Ecología Animal for its logistic support in fieldwork. To Rodrigo Bernal, editor of the manuscript who went beyond his duties and made important commentaries to improve the manuscript. We also thank the Laboratorio de Imágenes of the Department of Biology of Universidad del Valle, for photography and technical support.

\section{References}

Arango, N., Armenteras, D., Castro, M., Gottsmann, T., Hernández, O. L., Matallana, C. L., Morales, M., Naranjo, L. G., Renjifo, L. M., Trujillo, L. F. \& Villareal, H. F. (2003). Vacíos de conservación del Sistema de Parques Nacionales Naturales de Colombia desde una perspectiva ecorregional. Bogotá D. C.: WWF (Fondo Mundial para la Naturaleza), Instituto de Investigación de Recursos Biológicos Alexander von Humboldt. 64 pp.

Autino, A.G., Claps, G.L. \& Barquez, R.M. (1999). Insectos ectoparásitos de murciélagos de las Yungas de la Argentina. Acta Zoológica Mexicana, 78, 119-169.
Autino, A.G. \& Claps, G.L. (2000). Catalogue of the ectoparasitic insects of the bats of Argentina. Insecta Mundi, 14(4), 193-209.

Arcila, A.M., Valderrama C. \& Chacón, P. (2012). Estado de fragmentación del bosque seco de la cuenca alta del río Cauca, Colombia. Biota Colombiana, 13(2), 86-101.

Armbrecht, I., Tischer, I. \& Chacón, P. (2001). Nested subsets and partition patterns in ant assemblages (Hymenoptera: Formicidae) of Colombian dry forest fragments. Pan-Pacific Entomologist, 77(3), 196-209.

Barbier, E. \& Graciolli, G. (2016). Community of bat flies (Streblidae and Nycteribiidae) on bats in the Cerrado of Central-West Brazil: hosts, aggregation, prevalence, infestation intensity, and infracommunities. Studies on Neotropical Fauna and Environment, 51, 176-187. https:/ / doi.org/10.1080/01650521.2016.1215042

Barbier, E. \& Bernard, E. (2017). From the Atlantic Forest to the borders of Amazonia: species richness, distribution, and host association of ectoparasitic flies (Diptera: Nycteribiidae and Streblidae) in northeastern Brazil. Parasitology research, 116(11), 30433055. https://doi.org/10.1007/s00436-017-5615-7

Beloto, P., Cotrim, C., Favorito, S., Graciollo, G., Amaku, M. \& Pinto-da-Rocha R. (2005). Bat flies (Diptera: Streblidae, Nycteribiidae) parasitic on bats (Mammalia: Chiroptera) at Parque Estadual da Cantareira, São Paulo, Brazil: parasitism rates and host-parasite associations. Memorias do Instituto Oswaldo Cruz, 100(1), 25-32.

https://doi.org/10.1590/S0074-02762005000100005

Bequaert, J.C. (1940). Moscas parásitas pupíparas de Colombia y Panamá. Revista de la Academia Colombiana de Ciencias Exactas Físicas y Naturales, 3(12), 414-418.

Blüthgen, N., Menzel, F. \& Blüthgen, N. (2006). Measuring specialization in species interaction networks. BMC ecology, 6(1), 9. https:// doi.org/10.1186/1472-6785-6-9

Calonge-Camargo, B. \& Pérez-Torres, J. (2018). Ectoparasites (Polyctenidae, Streblidae, Nycteribiidae) of bats (Mammalia: Chiroptera) from the Caribbean region of Colombia. THERYA, 9(2), 171-178. https://doi.org/10.12933/therya-18-492

Combes, C. (1991). Evolution of parasite life cycles. In Toft CA, Aeschlimann A, Bolis L. (eds) Parasite-host associations: coexistence or conflict? Oxford: Oxford University Press.

de Vasconcelos, P.F., Falcão, L.A.D., Graciolli, G. \& Borges, M.A.Z. (2016). Parasite-host interactions of bat flies (Diptera: Hippoboscoidea) in Brazilian tropical dry forests. Parasytology Research 115(1), 367-377. https:// doi.org/10.1007/ s00436-015-4757-8 
Díaz, M.M., Solari, S., Aguirre, L.F., Aguiar, L.M.S. \& Bárquez, R.M. (2016). Clave de identificación de los murciélagos de Sudamérica. Publicación Especial No2. Tucumán, Argentina: PCMA (Programa de Conservación de los Murciélagos de Argentina).

Dick, C.W. (2007). High host specificity of obligate ectoparasites. Ecological Entomology, 32(5), 446-450. https:// doi.org/10.1111/j.1365-2311.2007.00836.x

Dick, C.W. \& Gettinger, D. (2005). A faunal survey of streblid bat flies (Diptera: Streblidae) associated with bats in Paraguay. Journal of Parasitology, 91(5), 1015-1024. https:/ / doi.org/10.1645/GE-536R.1

Dick, C.W. \& Patterson, B.D. (2006). Bat flies: obligate ectoparasites of bats. In Morand S, Krasnov BR, Poulin R (eds.). Micromammals and 500 Macroparasites. Tokio: Springer-Verlag. pp. 179-194. https://doi.org/10.1007/978-4-431-36025-4_11

Dick, C.W. \& Patterson, B.D. (2007). Against all odds: explaining high host specificity in dispersal-prone parasites. International Journal for Parasitology, 37(8-9), 871-876. https:// doi.org/10.1016/j.ijpara.2007.02.004

Dick, C.W., Esbérard, C.E.L., Graciolli, G., Bergallo, H.G. \& Gettinger, D. (2009). Assessing host specificity of obligate ectoparasites in the absence of dispersal barriers. Parasitology Research, 105(5), 13451349. https:/ / doi.org/10.1007/ s00436-009-1563-1

Dick, C.W. \& Miller, J.A. (2010). Streblidae. In Brown, B.V., A. Borkent, J.M. Cumming, D.M. Wood, N.E. Woodley, \& M. Zumbado (Eds). Manual of Central American Diptera (Vol II). Ottawa: National Research Council Press.

Dick, C.W. \& Graciolli, G. (2013). Checklist of world Streblidae (Diptera: Hippoboscoidea). Center for Integrative Research, The Field Museum of Natural History, Chicago, Ill. Available from https:/ / www.researchgate.net. Accessed 30 september 2019.

Dick, C.W., Graciolli, G. \& Guerrero R. (2016). Family Streblidae. Zootaxa, 4122(1), 784-802. https://doi.org/10.11646/zootaxa.4122.1.67

Dittmar, K., Porter, M.L., Murray, S. \& Whiting, M.F. (2006). Molecular phylogenetic analysis of nycteribiid and streblid bat flies (Diptera: Brachycera, Calyptratae): Implications for host associations and phylogeographic origins. Molecular Phylogenetics and Evolution, 38(1), 155-170.

https://doi.org/10.1016/j.ympev.2005.06.008

Dormann, C. F., Fründ, J., Blüthgen, N. \& Gruber, B. (2009). Indices, graphs and null models: analyzing bipartite ecological networks. The Open Ecology Journal, 2(1), 7-2.

Durán, A., Álvarez, D. \& Graciolli, G. (2017). Ectoparasitic flies (Diptera, Streblidae) on bats (Mammalia, Chiroptera) in a dry tropical forest in the northern Colombia. Papéis avulsos de zoologia, 57(8), 105-111. https:// doi.org/10.11606/0031-1049.2017.57.08

Durán, A.A., Saldaña-Vázquez, R., Graciolli, G. \& Peinado L.C. (2019). Specialization and modularity of an antagonsitic ecological network in a dry tropical forest in northern Colombia. Acta Chiropterologica, 20(2), 503-510.

https:/ / doi.org/10.3161/15081109ACC2018.20.2.020

Fritz, G.N. (1983). Biology and ecology of bat flies (Diptera: Streblidae) on bats in the genus Carollia. Journal of Medical Entomology, 20(1), 1-10. https://doi.org/10.1093/jmedent/20.1.1

García, H., Corzo, G., Isaacs, P. \& Etter, A. (2014). Distribución y estado actual de los remanentes del bioma de bosque seco tropical en Colombia: Insumos para su gestión. In Pizano C, García H, (Editors). El bosque seco tropical en Colombia. Bogotá D.C.: Colombia: Instituto de Investigación de Recursos Biológicos Alexander von Humboldt (IAvH). pp. 229-251.

Gardner, A.L. (2007). Mammals of South America: marsupials, xenarthrans, shrews and bats. Chicago, USA: University of Chicago Press.

Graciolli, G. \& de Carvalho, J.B. (2001). Moscas ectoparásitas (Diptera, Hippoboscoidea) de morcegos (Mammalia, Chiroptera) do Estado do Paraná. II. Streblidae. Chave pictórica para géneros e espécies. Revista Brasileira de Zoología, 18(3), 907-960. https:/ / doi.org/10.1590/S0101-81752001000300026

Graciolli, G. \& Dick, C. W. (2004). A new species of Metelasmus (Diptera: Streblidae: Streblinae) from Southern South America. Zootaxa, 509, 1-8.

Guerrero, R. (1993). Catálogo de los Streblidae (Diptera: Pupipara) parásitos de murciélagos (Mammalia: Chiroptera) del nuevo mundo. I Clave para los generos y Nycterophiliinae. Acta Biologica Venezuelica, 14(4), 61-75.

Guerrero, R. (1994a). Catálogo de los Streblidae (Diptera: Pupipara) Parásitos de murciélagos (Mammalia: Chiroptera) del Nuevo Mundo. II. Los grupos: pallidus, caecus, major, uniformis y longipes del género Trichobius Gervais, 1844. Acta Biologica Venezuelica, 9, 1-18.

Guerrero, R. (1994b). Catálogo de los Streblidae (Diptera: Pupipara) parásitos de murciélagos (Mammalia: 
Chiroptera) del Nuevo Mundo. IV. Trichobiinae con alas desarrolladas. Boletín de Entomología Venezolana N. S., 9, 161-192.

Guerrero, R. (1995a). Catálogo de los Streblidae (Diptera: Pupipara) parásitos de murciélagos (Mammalia: Chiroptera) del Nuevo Mundo. III. Los grupos: dugesii, dunni y phyllostomae del Genero Trichobius Gervais, 1844. Acta Biologica Venezuelica, 15, 1-27.

Guerrero, R. (1995b). Catálogo de los Streblidae (Diptera: Pupipara) parásitos de murciélagos (Mammalia: Chiroptera) del Nuevo Mundo. V. Trichobiinae con alas reducidas o ausentes y misceláneos. Boletin de Entomología Venezolana N. S., 10, 135-160.

Guerrero, R. (1996). Catálogo de los Streblidae (Diptera: Pupipara) parásitos de murciélagos (Mammalia: Chiroptera) del Nuevo Mundo. VI. Streblinae. Acta Biologica Venezuelica, 16(2), 1-25.

Guerrero, R. (1997). Catálogo de los Streblidae (Diptera: Pupipara) parasitos de murciélagos (Mammalia: Chiroptera) del Nuevo Mundo. VII. Lista de especies, hospedadores y países. Acta Biologica Venezuelica, 17(1), 9-24.

Marinkelle, C.J. \& Grose, E. (1981). A list of ectoparasites of Colombian bats. Revista de Biología Tropical 29(1), 11-20.

Marshall, A.G. (1981). The ecology of Ectoparasites Insects. Academic Press, London.

Montoya-Bustamante, S., González-Chávez, B. \& Giraldo, A. (2013). Quirópteros de bosque seco tropical en el municipio Santander de Quilichao, Cauca, 247 registros. En línea, https:/ / ipt.biodiversidad. $\mathrm{co} / \mathrm{sib} /$ resource? $\mathrm{r}=$ chiropteros_quilicha

Montoya-Bustamante, S., Rojas-Díaz, V. \& TorresGonzález, A.M. (2016). Interactions between frugivorous bats (Chiroptera: Phyllostomidae) and Piper tuberculatum (Piperaceae) in a tropical dry forest in Valle del Cauca, Colombia. Revista de Biología Tropical, 64(2), 701-713. https://doi.org/10.15517/rbt.v64i2.20689

Morse, S., Bush, S., Patterson, B., Dick, C., Gruwell, M. \& Dittmar, K. (2013). Evolution, multiple acquisition and localization of endosymbionts in bat flies (Diptera: Hippoboscoidea: Streblidae and Nycteribiidae). Applied and Environmental Microbiology, 79(9), 2952-2961. https:// doi.org/10.1128/AEM.03814-12

Overal, W.L. (1980). Host-relations of the batfly, Megistopoda aranea (Diptera: Streblidae) in Panamá. University of Kansas Science Bulletin, 52, 1-20.

Patefield, W. M. (1981). Algorithm AS 159: an efficient method of generating $\mathrm{r} \times \mathrm{c}$ tables with given row and column totals. Journal of the Royal Statistical Society. Series C (Applied Statistics), 30, 91-97.

Pilosof, S., Dick, C. W., Korine, C., Patterson, B. D. \& Krasnov, B. R. (2012). Effects of anthropogenic disturbance and climate on patterns of bat fly parasitism. PLoS ONE, 7(7), e41487.

https:// doi.org/10.1371/journal.pone.0041487

Pizano, C. \& García, H. (2014). El bosque seco tropical en Colombia. Bogotá D.C.: Colombia: Instituto de Investigación de Recursos Biológicos Alexander von Humboldt (IAvH).

R. Core Team. (2014). R: A Language and environment for statistical computing. Vienna (Austria): R Foundation for Statistical Computing.

Ramírez-Chaves, H.E. \& Pérez, W.A. (2010). Mamíferos (Mammalia: Theria) del departamento del Cauca, Colombia. Biota Colombiana, 11(1-2), 141-171.

Solari, S., Muñoz-Saba, Y., Rodríguez- Mahecha, J., Defler, T., Ramírez-Chaves, H. \& Trujillo, F. (2013). Riqueza, endemismo y conservación de los mamíferos de Colombia. Mastozoología Neotropical, 20(2), 301-365.

Tarquino-Carbonell, A., Gutiérrez-Díaz, K.A., GalindoEspinosa, E.Y., Reinoso-Flórez, G., Solari, S. \& Guerrero, R. (2015). Ectoparasites associated with bats in northeastern Tolima, Colombia. Mastozoología neotropical, 22(2), 349-358.

Tamsitt, J.R. \& Fox, I. (1970). Records of bat ectoparasites from the Caribbean Region (Siphonaptera, Acarina, Diptera). Canadian Journal Zoological, 48(5), 1093-1097. https:// doi.org/10.1139/z70-193

ter Hofstede, H.M, Fenton M.B. \& Whitaker, Jr.J. (2004). Host and host-site specificity of bat flies (Diptera: Streblidae and Nycteribiidae) on Neotropical bats (Chiroptera). Canadian Journal Zoological, 82(2), 616626. https:// doi.org/10.1139/z04-030

Urbieta G.L., Torres, J.M., Dos Anjos, E.A.C., Carvalho, C.M.E. \& Graciolli, G. (2019). Parasitism of bat flies (Nycteribiidae and Streblidae) on bats in urban environments: lower prevalence, infracommunities, and specificity. Acta Chiropterologica 20(2), 511- 518. https:/ / doi.org/10.3161/15081109ACC2018.20.2.021

Wenzel, R.L. (1976). The Streblid batflies of Venezuela (Diptera: Streblidae). Brigham Young University Science Bulletin, 20, 1-177.

Wenzel, R.L, Tipton, V.J. \& Kiewlicz, A. (1966). The streblid batflies of Panama (Diptera: Calypterae: Streblidae). In Wenzel RL, Tipton VJ, (Editors). Ectoparasites of Panama. Chigago, USA: Field Museum. pp. 405-675. https:// doi.org/10.5962/bhl.title.2633 
Zarazúa-Carbajal, M., Saldaña-Vázquez, R. A., SandovalRuiz, C. A., Stoner, K. E. \& Benítez-Malvido, J. (2016). The specificity of host-bat fly interaction networks across vegetation and seasonal variation.

Parasitology Research, 115(10), 4037-4044.

https://doi.org/10.1007/s00436-016-5176-1 
Oscar Ascuntar-Osnas

Universidad del Valle

Santiago de Cali, Colombia

askuntar.osnas@gmail.com

https://orcid.org/0000-0002-8621-037X

Sebastián Montoya-Bustamante

Universidad de São Paulo

São Paulo, Brasil

s.montoyabustamante@gmail.com

https://orcid.org/0000-0002-3699-2596

\section{Baltazar González-Chávez}

Centro de Investigación Esquel de Montaña y Estepa Patagónica,

CONICET

Esquel, Argentina

baltazargch@gmail.com

https://orcid.org/0000-0001-5805-8107

Recibido: 13 de agosto de 2019

Aceptado: 12 de diciembre de 2019 